Historic, Archive Document

Do not assume content reflects current scientific knowledge, policies, or practices. 


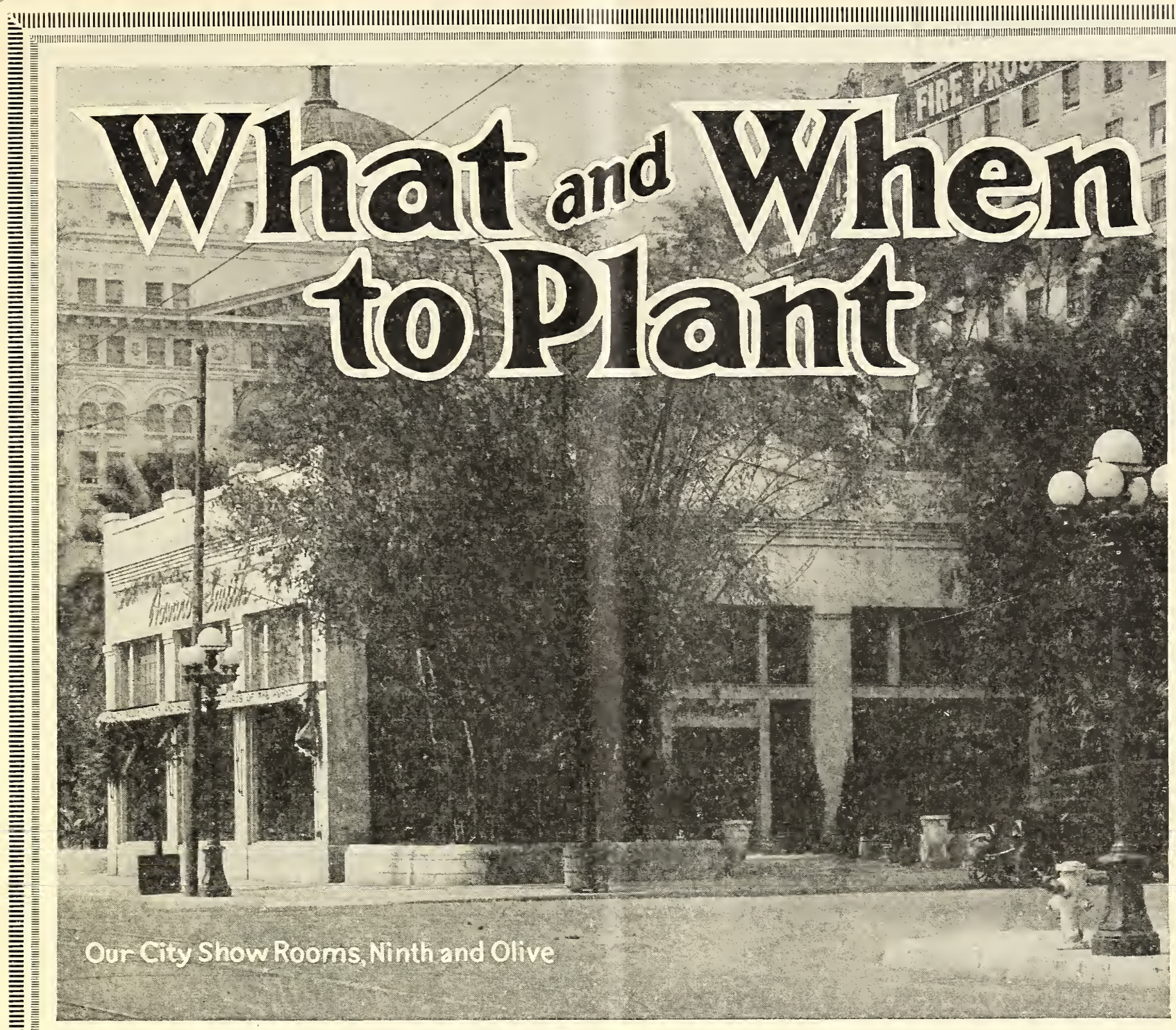

\section{AUTUMN and WINTER}

SEASON of 1922

FTER the trees and flowers and all other varieties of the vegetable kingdom were created the first agricultural activity of which we have any authentic knowledge was (1) the planting of a garden. Since then, down through all the ages, man has emulated 20 first example and, no doubt, improved on it. To one passing along the attractive avenues in the residence district of any community the beauty of the picture does not lie so much in the architectural designs of the builder, monuments to man's constructive ability in home making, as in the external environment made possible by the use of nature's setting. Aside from the formal use of trees and shrubs and lawn, we wish everyone could know the joy of a flower garden; could form an intimate relation with the glory of ever changing bloom as the successive seasons come, and could realize that it is a recreation, not a labor, and a sure path to wealth, health and the pursuit of happiness.

Now is the Time to Plant

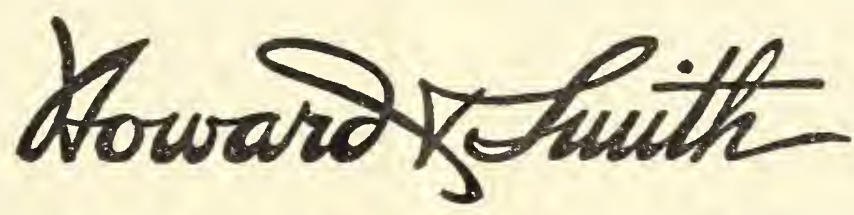

Olive Street at Ninth

Los Angeles, California

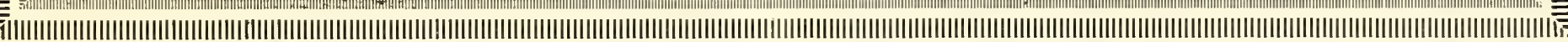




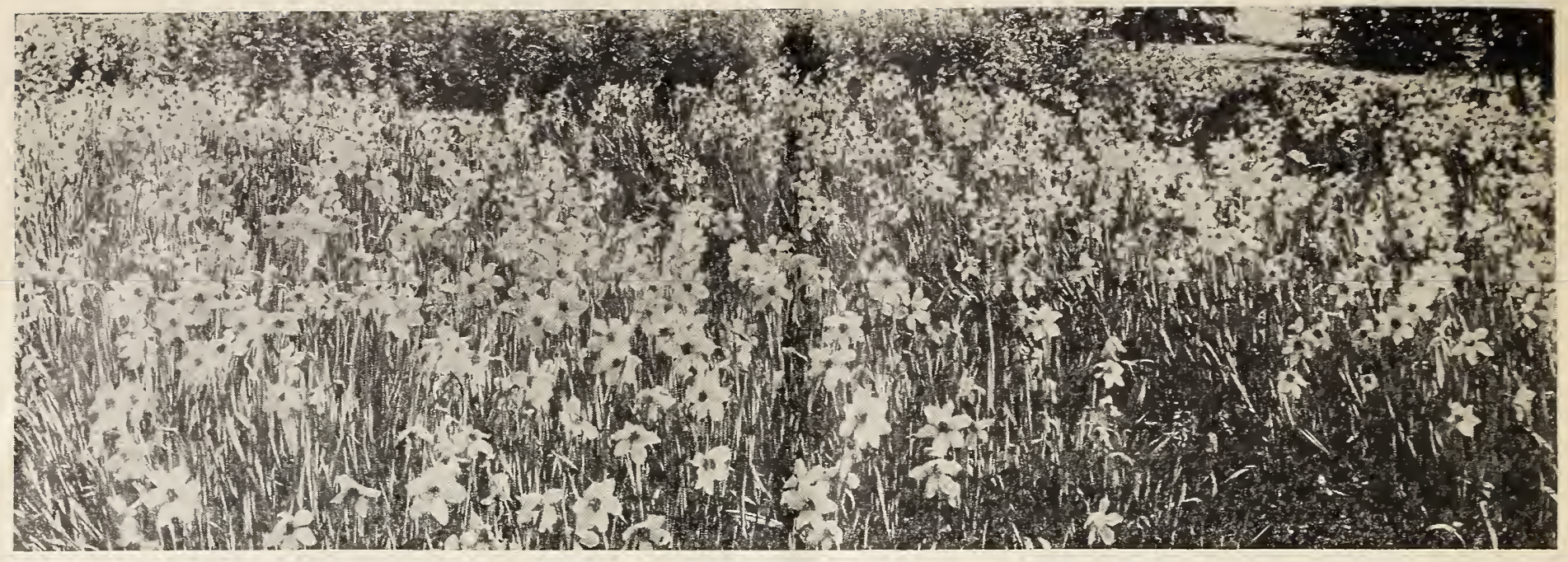

Narcissus Sir Watkin at our Rivera Nurseries

\section{Narcissus (Daffodils)}

Among the various bulbous plants of Spring there is nothing to exceed the beauty of well grown Narcissi. Their culture is simple to a degree, and when accorded proper conditions with the return of each Spring there is an increased display of bloom. The varieties in the subjoined list are good free growers ard produce plerty of blooms, the bulbs quoted are all selected first size.

Barri Conspicuus Flower extra large, perianth soft yellow, cup short, edged with orange scarlet. A splendid, strong grower, free flowering, extra fine. Price 10c each. $\$ 1.00$ per dozen. $\$ 7.50$ per 100 .

Emperor Flowers of large size with well expanded trumpet and splendid stem. One of the best for general bedding purposes. Price $10 \mathrm{c}$ each. $\$ 1.00$ per dozen. $\$ 7.50$ per 100 .

Empress Identical in every respect with the variety Emperor except the color-the perianth being white while the trumpet is a full rich yellow. Price 10c each. $\$ 1.00$ per dozen. $\$ 7.50$ per 100 .

Golden Spur A very early pure yellow trumpet daffodil. It comes in some weeks before Emperor and Empress and materially lengthens the flowering period of these bulbous plants. Price 10c each. \$1.00 per dozen. \$7.50 per 100 .

Golden Phoenix Large double flowers, handsome shade of yellow. Splendid for cutting purposes. Price 10c each. $\$ 1.00$ per dozen. $\$ 7.50$ per 100 .

King Alfred Easily one of the grandest of all the Narcissus. Color is a clear even yellow. Flowers of immense size, on well grown plants, attain a diameter of four inches and over. Extra fine first size bulbs. Price 25c each. $\$ 2.50$ per dozen.

Orange Phoenix Large perfectly double daffodil. Petals white and orange. One of the best of all the perfectly double types. Price 10c each. \$1.00 per dozen. $\$ 7.50$ per 100.

Poetaz Aspasia A bunch flowered daffodil. Perianth pure white, cup rich golden yellow. The individual blossoms are true Poeticus type in form. Stems very long. Excellent for cutting purposes. Price $10 \mathrm{c}$ each. $75 \mathrm{c}$ per dozen. $\$ 5.50$ per 100.

Poetaz Elvira Similar to the preceding in form. Stems are surmounted by three to four large flowers. The petals are broad, pure white, the cup golden yellow distinctly edged with

orange, exceedingly fragrant. Attains a height of some 24 inches. Price $10 \mathrm{c}$ each. $75 \mathrm{c}$ per dozen. $\$ 5.50$ per 100.

Princeps One of the earliest blooming of all narcissus, similar to Empress in appearance, but a little smaller in size; perianth sulphur white with long yellow trumpet.

Price $\$ 1.00$ per dozen; $\$ 7.50$ per 100 .

Sir Watkins Perianth sulphur yellow. cup bright vellow beautifully rimmed with bright orange. Price 10c each. $\$ 1.00$ per dozen. $\$ 7.50$ per 100 .

Robt. Sydenham Color sulphur yellow, flowers beautifully formed. The broadly expanded perianth forms an ideal background for its frilled trumpet. Price $\$ 1.50$ per dozen; $\$ 10.00$ per 100.

$V$ an Waveren's Giant A new variety. Blossoms of enormous size. Perianth primrose and of companulate form. Trumpet bright orange yellow. Mouth of trumpet flared and beautifully ruffled. Easily one of the finest daffodils in cultivation today. Price $25 \mathrm{c}$ each. $\$ 2.50$ per dozen.

Von Sion Similar in general form to the ordinary trumpet daffodil with the exception that the center of the flower is quite double. Color rich golden yellow. Very desirable for cutting purposes. Price $10 \mathrm{c}$ each. $\$ 1.00$ per dozen. $\$ 7.50$ per 100 .

Victoria Very large erectly borne flowers. Perianth delicate creamy white. Trumpet clear rich yellow. Price $10 \mathrm{c}$ each. $\$ 1.00$ per dozen. $\$ 7.50$ per 100 .

CULTURAL NOTE Narcissis thrive in a light, rich soil, and when possible, they should be planted in a bed by themselves. After the blooming season water should be witheld and the bulbs allowed to ripen in the usual manner. The water required to keen other plants alive during the sum. mer months is especially harmful to them. Plant the bulbs four or five inches deep and six to eight inches apart. After a growth of a few inches is attained, give a good liberal mulch of well rotted manure.

\section{Narcissus (Jonquils)}

This variety of narcissus is so well krown that there is little description necessary. The flowers are generally small and flat, the cup being quite short. The blossoms are usually borne four or five to a stem. Jonquils are ideal for cutting purposes, being splendid subjects to mix with other flowers in spring baskets.

CHINESE SACRED LILY (Water Jorquil)

One of the finest of all flowers for indoor purposes-grown all over the world, in the spring of the year, in bowls as house plants. There could be nothing more beautiful in the home than a bowl of Chinese lilies, as they are intensely fragrant and bloom over a long period of time. We have procured a large shipment of first size bulbs direct from China. Price $25 \mathrm{c}$ each; $\$ 2.50$ per dozen.

\section{SINGLE JONOUIL CAMPERNELLI}

One of the most free flowering of all jonquils. Like most flowers of this type, the blossoms are borne in clusters. The bright yellow blooms stand well above the foliage and are borne in clusters. The bright yellow blooms stand well above the foliage and are borne on stiff, strong stems, which makes them ideal for cutting purposes as well as being very showy in the garden. Price $75 \mathrm{c}$ per dozen; $\$ 5.50$ per 100 .

\section{DOUBLE JONQUIL CAMPERNELLI}

An exact replica of the foregoing with the exception that the center of the cup is double which gives the Alower a fuller appearance. Price 75c per dozen; $\$ 5.50$ per 100.

\section{SOLIEL D'OR}

A miniature form of jonquil that is always prized for its wonderful fragrance and distinctive appearance. The foliage is very graceful and grasslike which makes a fitting background for the dainty little blossoms of orange and gold. Price $75 \mathrm{c}$ per dozen; $\$ 5.50$ per 100 . 


\section{Darwin Tulips}

We offer a splendid assortment of these best of all Tulips including all shades and colors. While there are many classes of tulips, it has been fully demonstrated that those of the Darwir class give the best results urder the climatic conditions of California.

The followirg 10 varieties are the best in their respective colors:

Baronne de la Tonnaye-vivid rose.

Clara Butt-soft rose.

Europe-scarlet with blue base.

Euterpe-lilac.

Glow-brilliant glowing vermillion, center blue. margined white.

Inglescombe Yellow Bright canary reliow. best of all rellow tulips.

Mrs. Farncombe Sanders-bright scarlet.

Pride of Haarlem-brilliant rosy red.

Mad. Krelage--bright lilac rose.

Philipe de Commines-velvety dark purple.

$10 \mathrm{c}$ each; $\$ 1.00$ per dozen; $\$ 7.00$ per 100 .

\section{BREEDER TULIPS}

In this race of tulips will be found many beautif ul colors and shades that do not exist in the Darwin type. Shades of bronze, lilac and heliotrope predominate ard there is a pronourced glaze over the petals, creating a metallic effect that is striking and distinct.

Bronze Queen Splendid either for the open grourd or for pot culture. Color soft buff toned with apricot and gold.
Godet Parfait Deep purple, shaded violet with white at the base of the petals. Splendid long stems, ideal for cutting purposes.

Jaune D'Oeuf Deep golden blooms with the outer side of the petals shading to apricot.

Mac Mahon Bronze violet margined with bronze vellow. Very large and striking.

Medea Enormous flowers, crushed strawberry shaded with heliotrope; yellow center.

Prince of Orange Deep terra cotta with orange margir. A wonderful color combination.

Each 15c, \$1.50 per doz., $\$ 10.00$ per 100.

CULTURAL NOTE These Tulips should be planted in any sunny plot in the garden in good sandy loam. If the soil is at all heavy it would be advisable to excavate the bed to a depth of 10 inches, replacing with good loam and a liberal addition of well rotted cow manure. Fill the beds four to five inches above the surrounding ground level, tread firmly, rake to a smooth even surface and plant the bulbs in lines four inches apart and four inches deep. Place a ridge around the edge, so the bed may be flooded, as sprinkling is injurious and tends to destroy the blooms when open.

\section{Gladiolus}

The remarkable improvement made in Gladiolus during recent years and the numerous fine strains now obtainable, have served to greatly increase the culture of these lovely summer blooming bulbs. We grow at our Rivera Nursery, a collection which is in point of quality, second to none in America. For years, we have been patiently hybridizing the best sorts and making selections of the finest types of resultant seedlings, until today we question if there is a better collection obtainable anywhere. Our prize mixed hybrids are remarkable for the immerse size of their blos. som and the vigor of the plarts. We are certain they will please the most critical.

Byron Smith A novelty in gladiolus that marks an epoch in the culture of this beautiful flower. A variety distinct from all others in coloring. The wonderful shades in this flower equal, if not surpass, the finest orchids in color tone. The throat of old ivory merges to delicate mauve, developing as the flower expands to an exquisite shade of orchid. A frost-like sheen over the petals gives the whole a transparert appearance that is truly transcendent in its beauty. Each 35c; per dozen $\$ 3.50$.

Mary Pickford Awarded the certificate of merit by the Royal Horticultural Society of London in 1920. The flowers are of splendid size and form, color creamy white with soft shadings of lemon yellow at the throat. The stalks attain a height of thirty inches. The flowers are well placed on the stalk, six or seven being open at one time. The Mary Pickford is an ideal flower. In the lighter colored section there is rothing that can surpass it. Each $35 \mathrm{c}$; per dozen $\$ 3.50$.

Gladiolus America Our bulbs of this season's crop are es. pecially fine. If planted now they will give you during early Spring an abundance of flowers. The blossoms of this variety are large, well expanded, with eight to ten open on a spike at a single time. The color is an exquisite shade of pink. Successive plantings may be made, say three or four weeks apart. By doing this the period during which they will blos. som may be extended considerably. Last planting may be made as late as March or April. Extra fine bulbs. Each 10c; per dozen $\$ 1.00$.
Halley Beautiful salmon pink. Individual flowers very large and well formed. The plant is a sturdy grower, a very pop. ular market variety. Per dozen $\$ 1.00$. $\$ 7.00$ per 100

Mrs. Frank Pendleton One of the most recent introductions in Gladiolus. Blossoms of enormous size. The ground color is rosy pink, shading lighter at the edges. Throat beautifully blotched with deep crimson and maroon, with pencilings of scarlet reaching towards the edges of the petals. Plants vig. orous, stems strong and wiry. $\AA$ very fine cut flower variety. Per dozen $\$ 1.50$. $\$ 7.50$ per 100 .

Schwaben Color pale lemon yellow with a dash of red at the base of the throat. An excellent variety for cutting. Large full flowers closely set on spike. It is a gladiolus of recent introduction and without question it is the best in the light yellow section. Price $\$ 1.50$ per dozen. $\$ 7.50$ per 100 .

H. \& S. Prize Mixed Hybrids Under this head we offer you a strain of mixed hybrids of superior quality. Contained in the mixture this season are many new colors with flowers of mammoth size. We do not believe there is anything in the gladiolus line which will equal or surpass them. Extra selected bulbs in a superb mixture of colors. Each $15 \mathrm{c}$; per dozen $\$ 1.50$.

Faust This grand variety bears large flowers of rich carmine red. Blossoms well expanded when open. We highly recommend this variety for its rich coloring and for the quality of its flowers. Price 10c each; $\$ 1.00$ per dozen.

Willy Wigman Beautiful soft rose, with dark blood red blotches. A splendid variety. Price $15 \mathrm{c}$ each; $\$ 1.50$ per doz. 


\section{Hyacinths}

We have a very fine lot of extra selected, first sized bulbs to offer this Fall. They may be planted at any time from September to December. The earlier the better. When planting in the open ground, select a rich light soil, and cover the bulbs three to four inches above the crown. For pot culture, use a four-inch pot, and allow the top of the bulb to come even with the soil. Store in a dark, cool place for three to four weeks, keeping the soil moderately moist. They may then be removed to the greenhouse or conservatory.

Gerirude-crimson, rose, large spikes.

Gigantea-immense spikes of pale rose.

Grand Maitre-grand spikes of deep porcelain blue.

King of the Blues Dark blue, compact truss.

La Victoire-best of all the red hyacinths, bright glittering red--splendid large spikes.
L'Innocence-creamy white.

Lord Balfour-violet.

Queen of the Blues Pale azure blue, large spike, very beautiful.

Queen of the Pinks-lovely pink, immense spikes, good size bells

Yellow Hammer-best yellow.

Price 25c each. $\$ 2.00$ per dozen. $\$ 15.00$ per 100 .

\section{Ranunculus}

Our strain of these popular Spring flowering plants is of very superior quality. The blossoms are of giant size and the plants of exceptional vigor. They attain a height of 18 inches when in full bloom and the colors are of matchless beauty. Price $75 \mathrm{c}$ per dozen. $\$ 5.00$ per 100 .

CULTURAL NOTE Before planting the roots soak them in water for two or three hours, this causes them to swell to full size. Plant them in a good rich soil, claws downward, six to eight inches apart each way and cover the roots with two inches of finely sifted soil. If a little care is used a glorious display will follow in the spring, extending over a period of several weeks.

\section{Freesias}

Giant Pink Flowers very large; equal to Purity in size. Color rich pure pink. Per dozen $75 \mathrm{c}$. $\$ 5.00$ per 100 .

Purity Large flowers of splendid quality. The best of all pure white Freesias. The blossoms have none of the objectional yellow shadings seen in the ordinary types. Per dozen 35 c. $\$ 2.50$ per 100 .

Refracta Alba The original well known form, intensely fragrant. Per dozen 25c. $\$ 1.50$ per 100 .

\section{RAINBOW MIXTURE}

For several years we have grown colored freesias, each year eliminating the objectionable shades. This season we offer a splendid collection of all colors mixed, including yellow, pink, bronze, gold, amber, etc. These freesias nearly equal the white in size and bloom in great profusion; splendid for cut flowers and also ideal for bordering beds or walks. If left in the ground they will multiply and produce a greater crop of flowers each succeeding season.

Price $75 \mathrm{c}$ per dozen; $\$ 5.00$ per 100

\section{Giant Single Anemones}

Single Giants (New.) A superb strain of Giant Anemones, containing a wonderful range of colors. They vary from purest white to pink, dazzling scarlet, crimson, purple, rariegated, with innumerable intervening shades. Flowers of enormous size reaching a diameter of five inches, and carried erect on stems fifteen inches long. Last Spring we had a large block of plants in bloom at one time, and they gained the admiration of all visitors at our nursery. In the way of Spring flowers, there is nothing that exceeds in beauty a well grown bed of Anemones, and no class of plants which require less attention. They may be planted in lines along a border, or mixed in with other bulbous plants. For best effect they require planting in masses. Strong pot plants, per doz., $\$ 1.00$; per $100, \$ 7.50$

\section{Amaryllis Hybrids}

Our magnificent strain of Amaryllis is second to none in this country. Any attempt to describe them, even with the most glowing adjectives, would fail to convey an adequate idea of their surpassing beauty. They range in color from the pure white ground color of rose, red, etc., to rich orange, scarlet, cherry, bright red, crimson, maroon, mottled, striped, etc. The flowers are flat and spreading with full rounded and overlapping petals. The entire strain bears flowers of enormous size, the blooms averaging from nine to ten inches in diameter with five and six to a single stem

Class A First size, selected flowering bulbs which will bloom this Spring. Perfect in color, form, size and substance. Every one a gem. Each $\$ 1.00$; per dozen $\$ 10.00$.

Class $B$ First size, selected bulbs, full flowering size, not ruite as perfect in form and color as the preceding but superior to any other strain on the market. Assorted colors. Each $75 \mathrm{c}$; per dozen $\$ 7.50$

1. GYPSUM:
Gypsum acts quickly on heavy soils. Under its action soils of a clay or adobe nature quickly disintegrate, freeing
the ingredients upon which plants live. Many soils of a heavy composition are rich in plant food, but this food
is not avalable because of the fact that the fibrous roots of small plants cannot penetrate it. GYPSUM will make
this plant food available. Apply one sack to every 300 square feet, turning it under the soil to a depth of three or
four inches. PRICE-100 pound sacks $\$ 1.50$.
2. SHEEP MANURE:
Without question one of the best of all animal fertilizers. Quickly applied, and under the action of water the fer-
tilizer contained in the manure is quickly liberated and becomes available for the growth of the plants. PRICE
-50 pound sacks 1.25 .
3. LAF MOLD:
There are certain plants, such as ferns, begonias, prim roses, cinerarias, etc., that require a great deal of humus.
There is no better way of adding humus to the soil than by digging in a quantity of well-rotted leaf mold, which
also makes the soil spongy and free, thus ensuring good drainage. Dig well into the soil so that it will become
thoroughly incorporated with the native ground. PRICE- 50 pound sacks \$1.50.




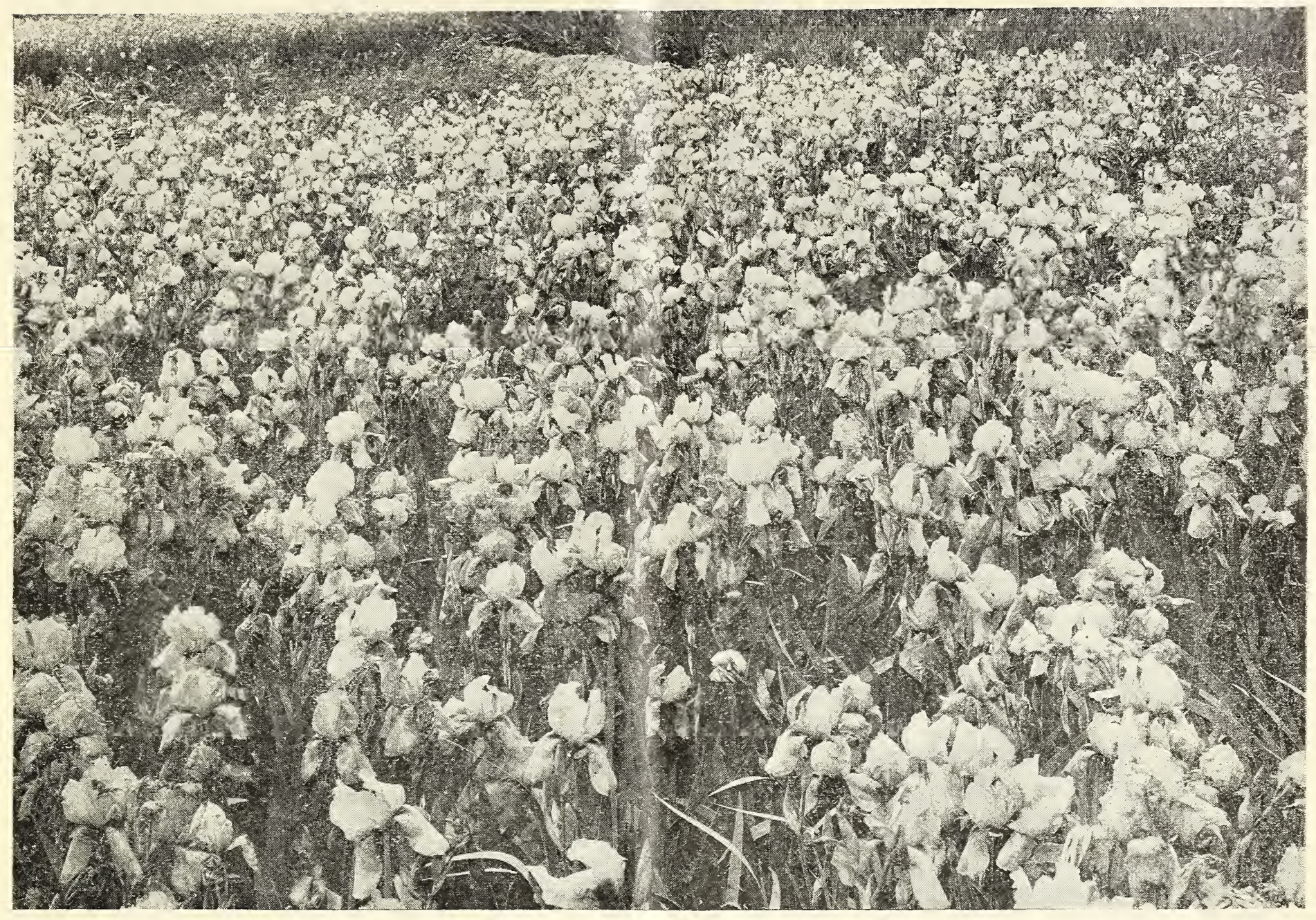

A bed of Iris Jeanne d'Arc at our Rivera Nurseries, a variety of great beauty

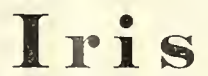

The collection which we offer below is a very select lot of these hardy blooming plants. Their adaptability to so many different uses places them in the front rank of our hardy garden plants. For the margins of woodland walls, shrubbery borders, wild gardens or near ponds they are unexcelled. They make splendid cut flowers, being equal to the choicest Orchids from point of beauty. For several years we have been gathering together a collection of the new giant flowered hybrids of the pallida type. For these are without question the coming Iris. The plants are of very vigorous growth, characterized by their broad foliage and splendid length of stems. The stems on many of the varieties which we offer below attain a height of four $f$ eet and over. In fact we have had Caterina, one of the Sir Michael Foster hybrids, an English raised variety, grow as high as five feet. A representative of our firm traveling through Europe in 1919, gathered together a superb collection of additional varieties which will be sent out when our stock permits.

The ease with which these Iris can be grown and their splendid value, not only as garden plants, but for use as cut flowers, should recommend them to every garden lover. At our Rivera nurseries, we grow them in large checks and doubt if a more magnificent sight can be conceived, than when these Iris are at the height of their glory, during the months of April and May.

\section{A collection of choice new and rare varieties}

Alcazar A truly magnificent Iris. Stems of great length. Blossoms of enormous size. Color a wonderful combination of violet, purple and blue. Price $35 \mathrm{c}$ each. $\$ 3.50$ per doz.

Amas Medium as to height. Strong sturdy stems surmounted by flowers of a delicate shade of lavender blue. The falls are violet blue. Price $35 \mathrm{c}$ each. $\$ 3.50$ per dozen.

Archeveque A unique color in this new class of Iris. Standards are a rich shade of reddish purple. Falls dark velvety purple. Price $35 c$ each. $\$ 3.50$ per dozen.

Caprice A variety characterized by its immense flowers and vigorous growth. Color a pure shade of violet blue. Highly recommended. Price $35 \mathrm{c}$ each. $\$ 3.50$ per dozen.

Caterina This superb variety is unquestionably one of the handsomest of all Iris. It is a giant, not only in height but also in the mammoth size of its blossoms. It attains a height of four to five feet. The stems are long and much branched, bearing as many as six and eight flowers, at a single time. The color is an exquisite shade of pure lavender blue, the color being uniform in both the standards and falls. Price 35c each. $\$ 3.50$ per dozen.

Cherubim This new Iris has standards of a distinct shade of lavender. Falls lavender veined with white. Price 50c each. $\$ 5.00$ per dozen.
Candelabre A grand variety with stems heavily branched. Flowers medium as to size. In color a lovely shade of pale blue, veined and marked with purple. Price 50c each. Per dozen $\$ 5.00$.

El Dorado One of the greatest advances as to color, in these new hybrids. A tall grower with very large flowers. The ground color is brownish yellow, overlaid with blue. Remarkably fine variety. Price $35 \mathrm{c}$ each. $\$ 3.50$ per dozen.

Isolene One of the finest Iris in existence. Standards pale lavender, falls light purple overlaid with brown, beard yellow. Each $50 \mathrm{c}$; dozen $\$ 5.00$.

Jeanne D'Arc One of the daintiest Iris in existence. The ground color is pure white, both in standards and falls, with pencilings of light blue over the entire surface of the petals. This variety is a remarkably free bloomer, and equal to the finest orchid in point of beauty. It is a variety which we highly recommend and no collection of Iris could be considered complete without it. Price $35 \mathrm{c}$ each. $\$ 3.50$ per dozen.

Loute Height medium. Flowers borne on stout sturdy stems very large as to size. Standards pale lilac, falls deep blue, Price $35 \mathrm{c}$ each. $\$ 3.50$ per dozen. 
Oriflamme Very large flowers. Standards clear light blue Falls rich lavender purple. Very fine. Price 35c each. $\$ 3.50$ per dozen.

Parisiana A distinct advance, by way of color, in these new Iris. The standards are mottled lavender pink. Falls creamy white, with a suffusion of pink. A scarce and high priced sort. Price $50 \mathrm{c}$ each. $\$ 5.00$ per dozen.

Nuee D'Orage A strikingly beautiful variety. Standards are a peculiar shade of grayish lavender. Falls bronze and purple. Blossoms of extra size. Very fine. Price $35 \mathrm{c}$ each. $\$ 3.50$ per dozen.

Tamerlane This variety bears flowers of phenomenal size. Well poised on thick heavy stems. Standards bright blue. Falls deep purple. Price $35 \mathrm{c}$ each. $\$ 3.50$ per dozen.

Prosper Laugier One of the most magnificent of all the new hybrids in the pallida type. The plant is a strong grower and a free bloomer. The color of the blossoms is unique and quite different to any other Iris to be noted in this set. Standards are light bronzy red, the falls are rich velvety maroon. The effect of the color of the falls being greatly enlivened by a distinct and heavy orange beard. A sort that should be in every garden. Price $₫ 5 \mathrm{c}$ each. $\$ 3.50$ per dozen.

Victoria Louise Medium as to height. Standards pale sulphur yellow. Falls rich plum color, shading to cream at the edges. Splendid combination of colors. $35 \mathrm{c}$ each. $\$ 2.50$ per dozen.

\section{INTERMEDIATE IRIS}

This set is distinct from the above, in that the plants ate somewhat lower in their growth and the fact that they flower a few weeks earlier than the varieties of the pallida type.

Ingeborg Pure white flowers of extra size. Elegant as to form. Price $25 \mathrm{c}$ each. $\$ 2.50$ per dozen.

Halfdan Standards and falls cream white. A distinct and meritorious sort. Price 25c each. $\$ 2.50$ per dozen.

Golden Fleece. Strikingly beautiful. Light yellow flowers. Blooming height about 18 inches. Very fine. Price 25c each. $\$ 2.50$ per dozen.

Lohengrin Blossoms of immense size. The color deep rich mauve. Price $35 \mathrm{c}$ each. $\$ 3.50$ per dozen.

Mrs. Reuthe A very free blooming early flowered variety. Standards and falls a delicate lavender blue. Extra choice. Price $35 \mathrm{c}$ each. $\$ 3.50$ per dozen

Walhalla Standards lavender. Falls wine red. 25c each. $\$ 2.50$ per dozen.

Zephyr Color lavender blue, blossoms of medium size only. What they lack in size, however, is more than made up for their profusicn of bloom. Price $35 \mathrm{c}$ each. $\$ 3.50$ per dozen.

\section{JAPANESE IRIS}

The latest introductions from Japan in this magnificent class of iris are marvels of beauty. The flowers often reach a diam eter of ten inches, and the colors and combinations of delicate shades in both single and double forms simply baffle description. Although they are among the easiest of all hris to biing to a state of perfection both as regards quality of bloom, height of growth, etc., we doubt if more failures occur in growing any plants than with these. This is simply due to lack of understanding regarding their requirements, and a careful read. ing of the cultural notes appended will be of service to our customers in securing the best results obtainable.

Our collection comprises over fifty of the very finest varieties in existence. The clumps which we offer are grown at our Rivera bulb fields and are models of health and vigor. We offer you an unsurpassed collection of about fifty varieties, double and single blossoms, all colors mixed. Large clumps. Each $50 \mathrm{c}$; per dozen $\$ 5.00$.

Second size clumps. Each 35c; per dozen \$3.50.

CULTURAL NOTE Select a plot of ground of suitable size for the number of clumps to be planted, allowing a minimum distance between the clumps of eighteen inches. Spade this over thoroughly to a depth of twelve inches, breaking all lumps, removing all stones, etc. Cover this with three inches of rotted cow manure, spade in and respade several times to thoroughly incorporate the manure,

Section off into beds four feet wide and as long as required with a path between, say of eighteen inches. Rake to a ridge four inches in height at the edges, so that the interior portion may be flooded with water, plant the clumps the distance above specified and cover the crown three inches deep. After plant ing flood with water, the beds if made perfectly level with good ridges at the edges, will hold water to a depth of three inches. After the first soaking give water in moderate amounts only until the growth begins. When the plants attain a height of six to eight inches they should be kept constantly wet. During the growing season give two or three mulchings of well rotted manure. This, through the flooding method, provides them with the equivalent of liquid manure and tends to increase the height of the stems and beauty of the bloom. If the weather is hot a lath shading placed over the beds at a height of seven feet (the lath nailed to strips three-quarters of an inch apart) tends to lengthen the blooming period and betters the quality of the flowers.

\section{TUBEROSES}

Well known and universally admired for their pretty spikes of waxy white and deliciously scented flowers. We offer you splendid roots of these ready for delivery from December on. Each 15c; per dozen $\$ 1.50$.

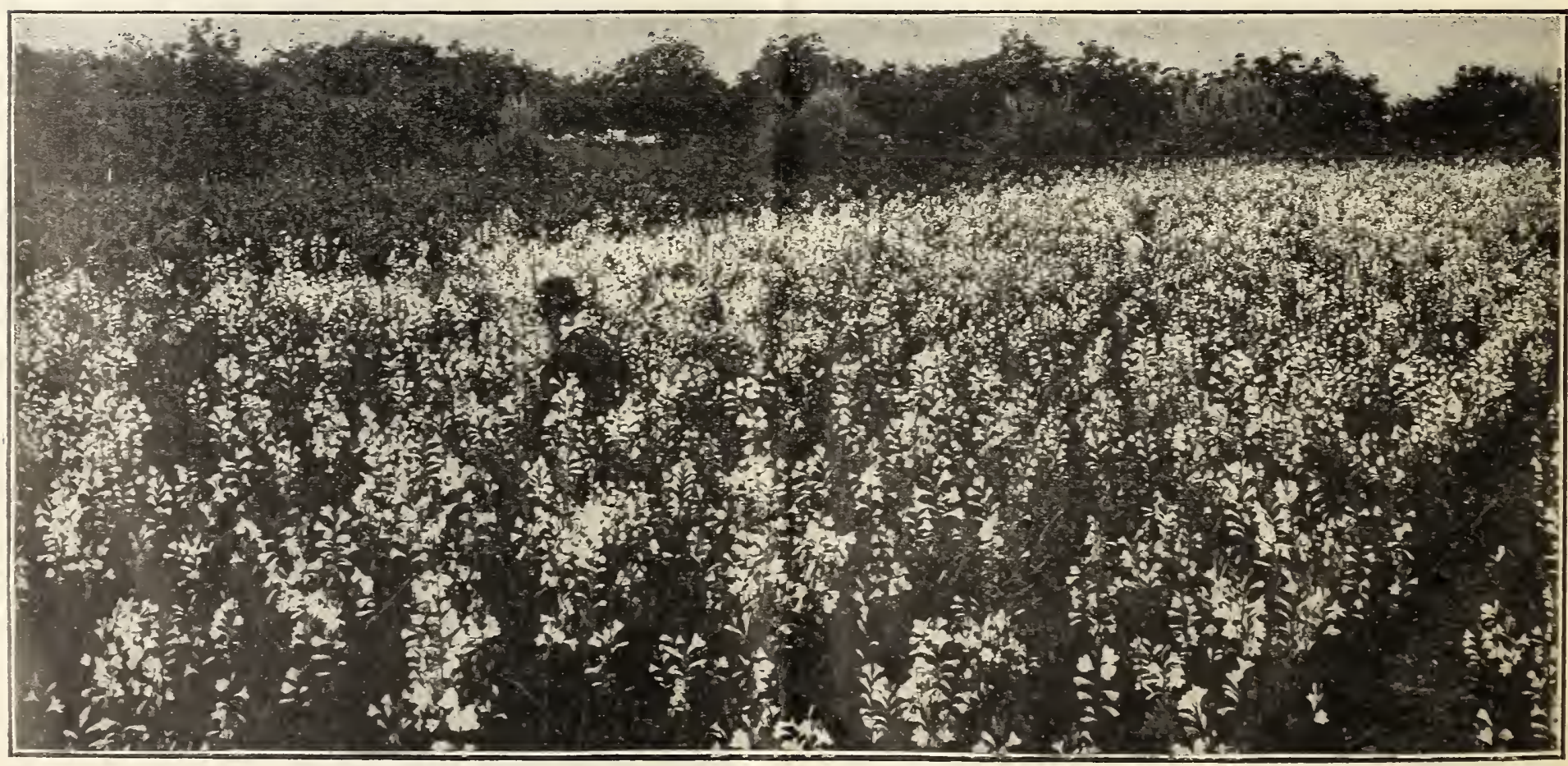

Field view of Watsonias at our Montebello Nurseries 


\section{Agapanthus Umbellatus}

Among the various Summer flowering bulbs there are but few which grow as easily or are more effective in the garden in so far as their bloom is concerned than well grown clumps of Agapanthus: This variety produces a continual succession of strong flower stems, each crowned with large umbels of deep blue flowers. Price $25 \mathrm{c}$ each. Per dozen $\$ 3.50$.

\section{Lycoris Squamigera}

A little known bulbous plant similar in form and color wo the Amaryllis Belladonna, but differing from it in its time of bloom. It sends forth in August strong spikes of bloom of a beautiful pink shade. Strong bulbs, each 35c. Per dozen $\$ 3.50$.

\section{Calla Lilly}

Richardia Aethiopica The well known Lily of the Nile. Fine strong roots. Each $20 \mathrm{c}$. Per dozen $\$ 2.00$.

Richardia Elliottiana The golden Calla. Flowers deep golden yellow. Foliage beautifully maculated with white on a green ground. Splendid for summer blooming. Each 35c. Per dozen $\$ 3.50$.

\section{Cyclamen}

We grow a large stock in a very choice strain of these well known Winter flowering plants and can supply them in all colors from pure white to deep crimson, including shades of salmon, pink, etc. Extra fine plant from 3-inch pots, each 35c. Per dozen $\$ 3.50$

\section{Ismene}

Calathina Grandiflora A beautiful free blooming bulbous plant from Brazil and one which is especially adaptable to culture in warm southern climates. The large blooms are in tensely fragrant, pure white in color with greenish bands in the base of the throat. The edges of the petals have a fringed outline which greatly enhances the beauty of the blooms. Strong bulbs, each 35c. Per dozen $\$ 3.50$.

\section{Amaryllis Belladona}

Lovely rose pink with a lighter colored throat. As this variety loses its foliage before the flower spikes issue forth, care must be taken not to disturb the bulbs at this period. Price 25c each. Per dozen $\$ 2.50$.

\section{Sternbergoia Lutea}

A little known bulbous plant flowering during the month of August bearing innumerable quantities of bright golden yellow flowers, similar in shape to a large Crocus. It is with out exception one of the brightest and most exquisitely colored flowers in cultivation today. The blossoms are borne on slender stems and attain a height of some 8 to 10 inches. The foliage is long and linear, light green in color, making a beautiful foil for the blossoms. These bulbs should be planted during the month of November or December for flowering the following year. Once planted they increase rapidly and flower in increased profusion season after season. Price $20 \mathrm{c}$ each. $\$ 2.00$ per dozen.

Spring Snow Flakes (Leucojum Vernum)

Similar in many respects to the popular lily of the valley but much more hardy and satisfactory than the latter under the climatic conditions of California. The stalks grow erect and strong to a height of about eight inches. Pendulant from each stalk hang five or six dainty bells. In each bell are four delicate spots of green which give the flowers a decidedly fresh and spring-like appearance. Per dozen $75 \mathrm{c}$; per $100 \$ 5.00$.

\section{Pink Watsonia}

A seedling sport of the well known white watsonia. The color is a delightful lavender pink. The blooms are produced on strong branching spikes five to six feet high and come into flower earlier than the white. Price $15 \mathrm{c}$ each; $\$ 1.50$ per dozen.

\section{Watsonia O'Brienii}

The finest of all white watsonias. Its lovely pure white flowers are produced on stems four to five feet high and in wonderful profusion. The usual time for flowering is about Easter time. Price 10 each; $\$ 1.00$ per dozen.

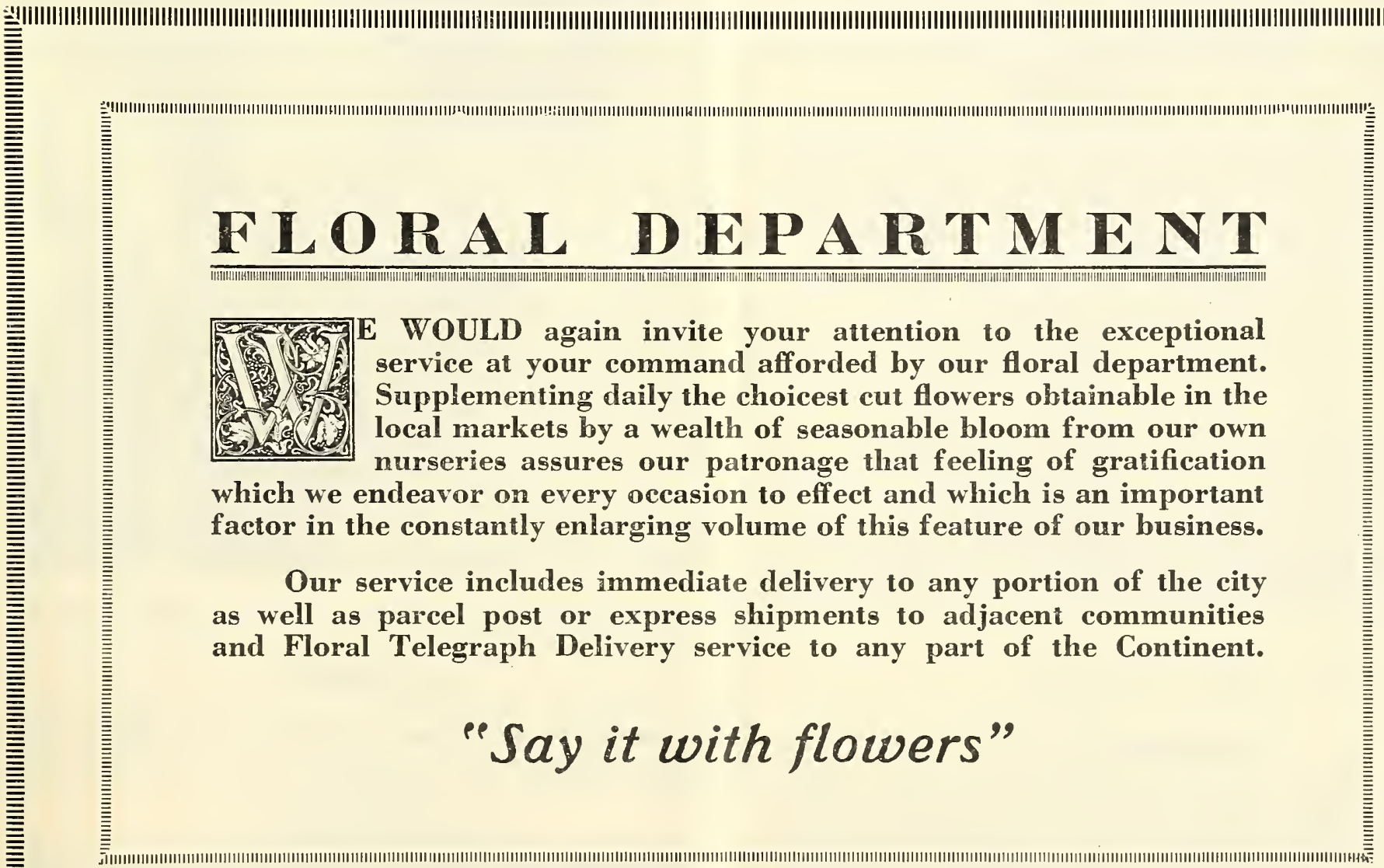




\section{Annual and Perennial Flowering Plants}

There are but few plants more popular today than that section usually classed under this heading. The value of Perennials, both hardy and tender, for planting in borders, beds, etc., is well recognized. Properly arranged herbaceous borders are a thing of beauty at practically all seasons of the year, and if the beds are properly prepared each succeeding season show an increased display of color. The collection which we offer you, while not a large one, contains a list of some of the best subjects adaptable for this work.

\section{AGATHEA}

Coelestis Commonly known as the Blue Marguerite. A charming old-fashioned plant which blooms continuously throughout a long period. Dwarf in habit. A splendid border plant for large beds. Each 15c; per dozen $\$ 1.50$.

\section{ANTIRRHINUM (SNAPDRAGON)}

A fine winter blooming annual. Each plant produces large quantities of tall, strong spikes, densely covered with beautiful flowers. In the last decade great improvements have been made in snapdragons. From a few uninteresting colors have been developed such shades as amber, fawn, scarlet, mauve, terra cotta, etc. The strain that we offer has been grown from the very finest European novelties. Price $75 \mathrm{c}$ per dozen; $\$ 5.00$ per 100 .

\section{AQUILEGIA (COLUMBINE)}

Hybrids of Coerulea The value of Columbines for bedding purposes, their beauty as cut flowers and their hardiness recommend them as one of the most useful of all perennial plants. We grow these by the thousand every year. Our strain is of the best long, spurred type and contains all shades from pure white to deep purple, including yellow, rose, red, pink, etc. Extra strong, field-grown clumps. Each $35 \mathrm{c}$; per dozen $\$ 3.50$. 2 inch pots, each $15 \mathrm{c}$; per dozen $\$ 1.50$.

\section{ASTERS (PERENNIAL)}

There is a large and growing demand for the various types of Perennial Asters. Their dainty, starry flowers and the wonderful profusion with which they are produced makes them striking subjects for flower borders, besides which they are of great value for mixing with bouquets, etc. We offer you a few of the best.

Beauty of Colwall A handsome double flowered light blue variety. Extra fine. Each 20c; per dozen $\$ 2.00$.

Abendrote An exceedingly choice sort with exquisite sky blue flowers. Each 20c; per dozen $\$ 2.00$.

Climax This is unquestionably one of the greatest additions to the list of Michaelmas Daisies or Perennial Asters ever made. The plants are of strong vigorous habit and the flower stems are covered with large, light blue lavender flowers. These attain a diameter of one and a half inches or more. An exquisite variety for cutting purposes. Each 35c; per dozen $\$ 3.50$.

Feltham Blue Handsome light blue flowers produced in dense masses. Each $25 \mathrm{c}$; per dozen $\$ 2.50$.

White Queen A superb white Perennial Aster. Produces great masses of starry white flowers. Each 20c; per dozen $\$ 2.00$.

\section{CALENDULA (Wirter-blooming Marigold)}

From our experience in flower culture we believe that there is scarcely any subject in the garden that will produce the amount of flowers and give the satisfaction that these beautiful marigolds will give during the winter months. They bloom at a time when few flowers are available and are ideal for cut flowers as well as for lending color and charm to the garden.

Orange King Deep golden yellow.

Lemon Queen Bright lemon yellow.

Price, per dozen $75 \mathrm{c}$; per $100 \$ 5.00$.

\section{CANTERBURY BELLS}

These charming old-fashioned plants are favorites with all and are among the most beautiful of our Spring flowers. They may be flowered in pots and when so grown are extremely pretty, their large, bell-shaped flowers showing to great advantage. We can supply these in a very high-class strain of the true cup and saucer type in all colors, including pure white, rose, blue, etc. Strong plants from three-inch pots. Each 15c; per dozen $\$ 1.50$.

\section{CENTAUREA CYANUS (CORNFLOWER)}

An old, well known favorite. Greatly prized for cutting purposes. We call special attention to our new double blue. This variety will produce 60 to 70 per cent of double blooms, the flowers being much larger than the old single type.

Double Blue $75 \mathrm{c}$ per dozen; $\$ 5.00$ per 100 .

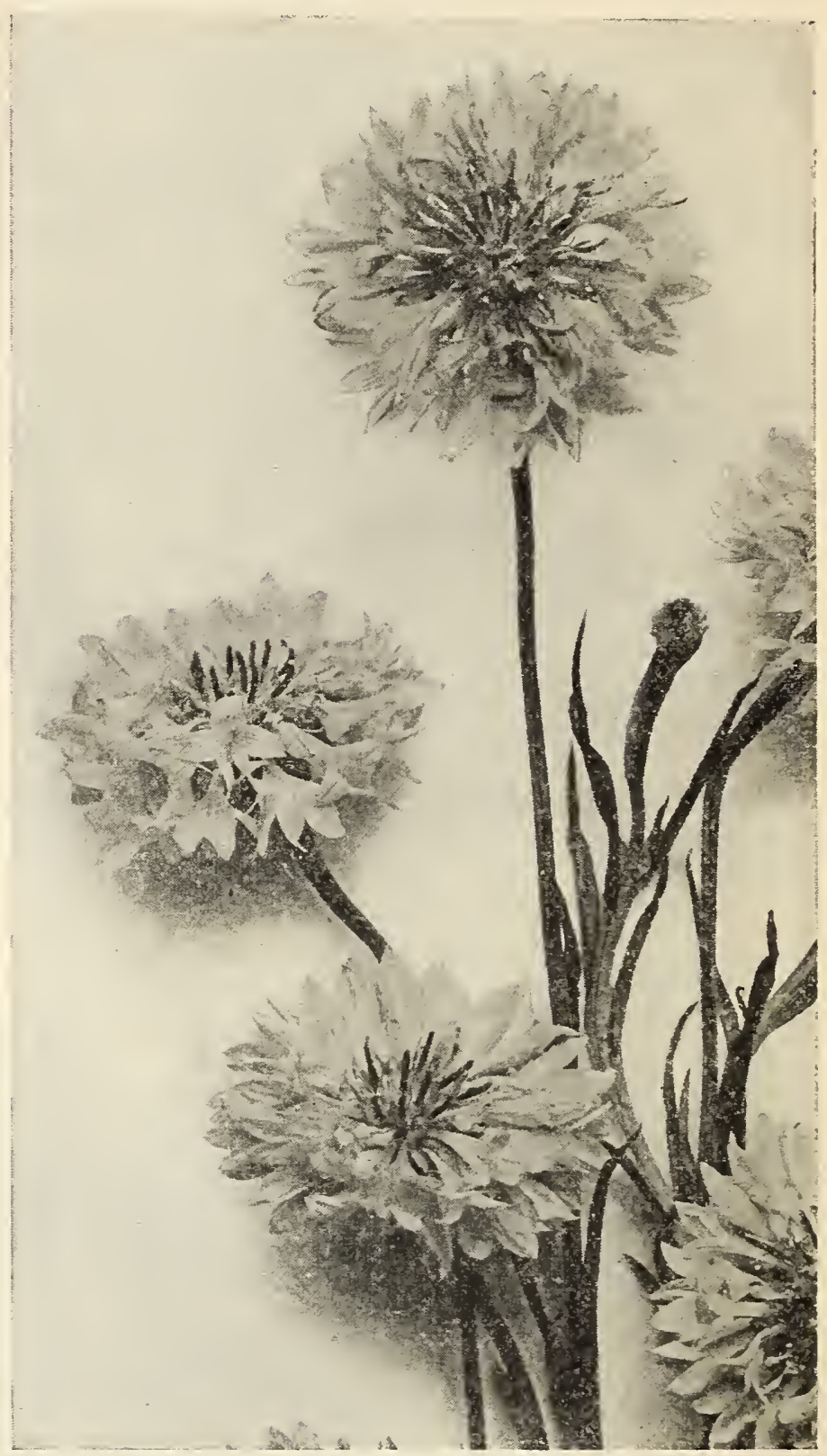

Corn Flower "Double Blue"-An Extra Fine Selection

\section{COREOPSIS}

Grandiflora A splendid plant for cut flower purposes, being covered for the greater portion of the year with endless quantities of golden blooms two or three inches across. Fine strong plants. Each 15c; per dozen $\$ 1.50$.

\section{DIGITALIS (FOXGLOVE)}

Handsome, hardy plants of sturdy growth, succeeding under the most adverse conditions. Spikes four to five feet high with giant flowers in all shades of color. Unequalled for naturalizing in shrubberies at the edge of woods or other half shady places. Mixed colors. Each $15 \mathrm{c} ; \$ 1.50$ per dozen. 
FORGET-ME-NOTS (Myosotis Dissitiflora)

The strain we offer is the very finest. The plants are compact and bushy in habit, producing flowers over a long period of time. The flowers are the most beautiful shade of cobalt blue, much more striking in tone than the very light blue type. Ideal for cut flowers. Price $\$ 1.00$ per dozen.

\section{GAZANIAS}

A splendid class of half-hardy plants growing only three to four inches in height and covered with flowers two to three inches in diameter. The following are two of the best:

Aurantiaca Yellow Beautiful pale yellow flowers. Each $15 \mathrm{c}$; per dozen $\$ 1.25$.

Aurantiaca Orange Similar to the above, but bright orange colored flowers. Each 15c; per dozen \$1.25.

\section{GYPSOPHILA}

Paniculata This handsome Gypsophila is the variety which is commonly used by florists for mixing with bouquets, etc. The plant attains a height of two to three feet, are much branched and covered in the Spring with innumerable minute pure white flowers. This variety is often referred to as Baby's Breath. Strong one-year clumps. Each $20 \mathrm{c}$; per dozen $\$ 2.00$.

\section{HEMEROCALLIS (JAPANESE DAY LILY)}

For the margin of ponds or for planting in the open border these lovely Japanese plants are of especial value. They form dense tufts of long narrow foliage surmounted by large trumpetshaped blooms. They are of perennial duration and require but little care beyond watering.

\section{FIVE VERY FINE VARIETIES}

Aurantiaca Enormous flowers, very sweetly scented. Color bright golden yellow. Each 35c; per dozen $\$ 3.50$.

Aurantiaca Major An improvement on Aurantiacas. The largest flowered variety in the family. Color rich orange. Each $50 \mathrm{c}$; per dozen $\$ 5.00$.

Florham A pure light yellow variety with medium size flowers. Blooms continuously from April to November. This variety is of especial value for herbaceous borders. Each 35c; per dozen $\$ 3.50$.

Sovereign A medium shade of yellow. Blossoms of good size and freely produced. Each $35 \mathrm{c}$; per dozen $\$ 3.50$.

Thunbergii A late flowering sort. Blossoms are quite small, borne on slender stems. Color a delicate shade of lemon yellow. Very sweetly scented. A veritable gem for rock work or for beds and borders. Each 35 ; per dozen $\$ 3.50$.

\section{HOLLYHOCKS}

The varieties which we offer have been carefully selected from our own prize collection. The flowers are of immense size, perfectly double and well arranged on tall handsome spikes. We can supply them in the following colors: Pure white, yellow, rose, shell pink, dark crimson and cherry red. The clumps which we offer this season are strong one-year stock which, if planted early in the Spring, may be depended upon to produce a glorious display during the following Summer. Extra strong clumps. Each $35 \mathrm{c}$; per dozen $\$ 3.50$.

\section{MARGUERITES}

These well known plants are favorites with all. They are of great value for border decoration, for planting along the margins of drives, etc. They bloom throughout the year in California and require but little care.

Mrs. Fred Sanders The finest of all double Marguerites. Produces large quantities of double, snowy white flowers. Strong plants. Each 25c; per dozen $\$ 2.50$.

Giant Yellow A splendid deep golden yellow Marguerite. Flowers single. Fine for cutting purposes. Each $20 \mathrm{c}$; per dozen $\$ 2.00$.

\section{PENSTEMONS}

Sensation A superb collection of Penstemons with large gloxinia-like flowers in all colors from pure white to darkest crimson with intervening shades of pink, scarlet, purple, rose, etc. Many of the blossoms are beautifully mottled and penciled in the throat. Strong plants from two-inch pots. Each $15 \mathrm{c}$; per dozen $\$ 1.50$.

\section{PERENNIAL LARKSPUR (DELPHINIUMS)}

Our strain of Delphiniums contains a wide selection of all the best shades of blue, ranging from the palest sky blue to indigo, sapphire, dark blue and purple. For producing a fine mass of blue Delphiniums are unequaled, and the fact that with the return of each season there is an increased quantity of bloom and added wealth of color has made them popular in gardens everywhere.

The clumps which we offer you are fine two-year-old stock which, if planted out early in the Spring, may be depended upon to give a wonderful show of color during the following Summer season.

H. \& S. Prize Mixed (Elatum Type) These are the tall growing Delphiniums with immense spikes of bloom which often attain a height of six to seven feet. They comprise a wonderful range of colors from palest to darkest blue, etc., with beautiful single and double forms of flowers. Fine strong clumps. Each $35 \mathrm{c}$; per dozen $\$ 3.50$.

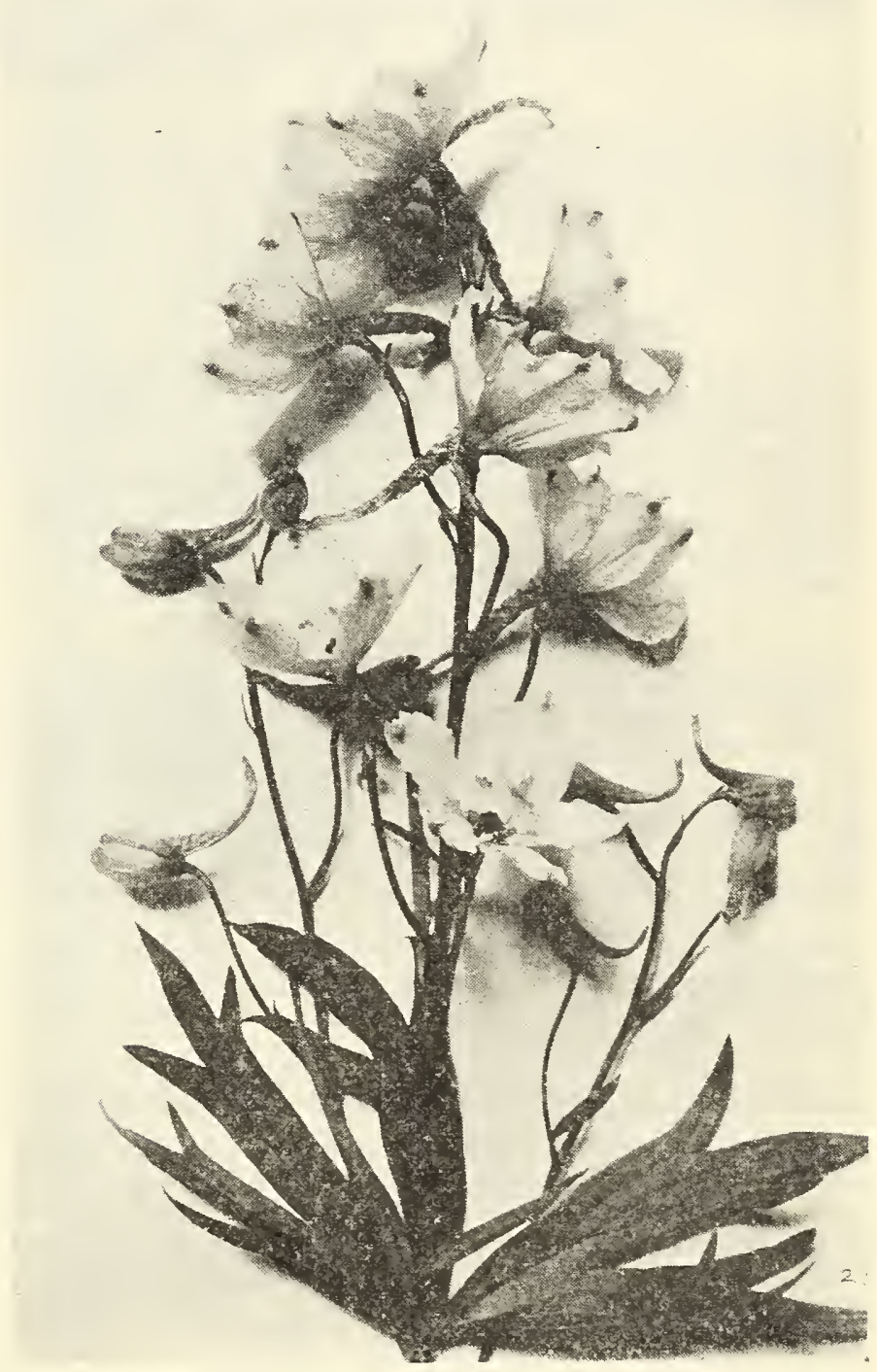

Delphinium Belladonua

Belladonna This beautiful Delphinium is unques. tionably ore of the most useful of all. It is quite distinct in character of growth from the preceding, being of a much dwarfer growth and of a much freer branching habit. It produces an uninterrupted show of bloom throughout the entire season. The stems are thin and wiry, the blooms quite large and beautifully poised on well arranged spikes. Sky blue in color.

Strong one-year clumps. Each 35c; per dozen $\$ 3.50$. 


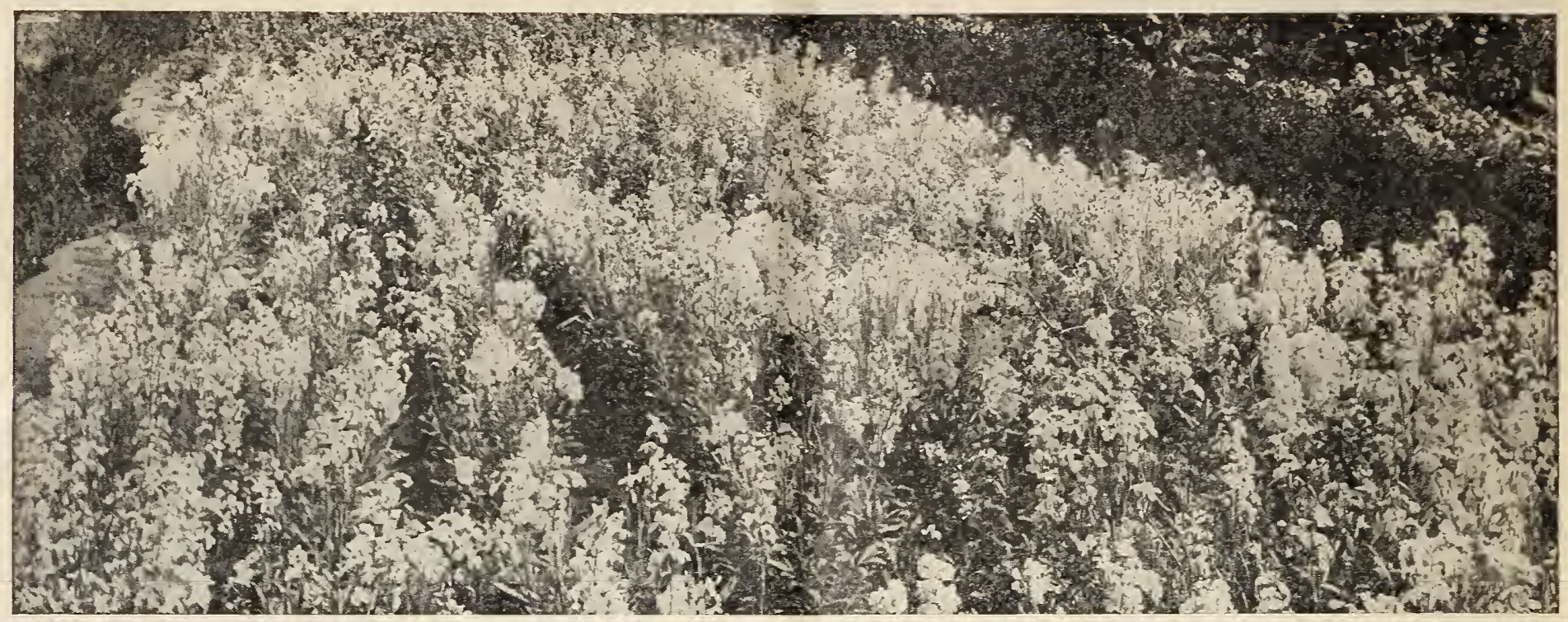

Stocks Growing for Seed at Our Trial Grounds

\section{Choice Specialties in Florists' Flower Seeds for Present Planting}

The following are a few of the more important seeds and it is essential that they be sown during the Autumn for blossoming the following Spring. The seeds offered are of the very finest quality obtainable. Full cultural notes appear on the face of each package of seeds, which we send out. If these directions are followed and a little care used, a bountiful supply of beautiful flowers during the coming Spring will result.

\section{H. \& S. PRIZE GIANT ANTIRRHINUMS (SNAPDRAGONS)}

The value of Snapdragons as a plant for producing masses of color in the garden or when used for cut flower purposes, is well known. The selections which we offer you are three colors of a giant strain which produce immense spikes of bloom with very large individual flowers in the spike. The plants when well grown attain a height of three feet and over. These varieties are exceedingly choice. Giant Yellow, Giant White and Giant Scarlet. Per packet 25c.

\section{CANTERBURY BELLS}

These favorite old-fashioned flowers thrive well in all sections of the country. Our strain of the Calycanthema or cup and saucer type is an exceedingly fine one. They come almost true to type, each blossom having its well defined cup and saucer form of bloom. There is a vast difference in the quality of the various strains to be noted under this heading. We believe you will find the seeds we offer you to be as good as you can possibly procure.

Calycanthema (Cup and saucer type). White, blue, bright rose, lavender, and all colors mixed. Packet $15 \mathrm{c}$.

Single Varieties A selection of clean and decided colors. White, rose, blue, mauve and mixed. Packet $15 \mathrm{c}$.

\section{CENTAUREA IMPERIALIS (GIANT SWEET SULTAN)}

A highly improved strain of Centaureas with flowers of mag. nificent size and a wide range of colors. Being good keepers in water, they are much prized as cut flowers. The distinctive character and informal shape of the blossoms add a grace and charm distinct from all other cultivated plants. Height 30 inches. Packet 10c.

Imperialis, White Extra large.

Imperialis, Rose. Dark Purple. Lilac. Mixed.

Suaveolens (Yellow Sweet Sultan) Like Centaurea Imperialis in general formation of bloom but with flowers of a lovely, pure, rich yellow.

\section{CENTAUREA CYANUS (Cornflower)}

An old, well known favorite. Greatly prized for cutting purposes. We call special attention to our new double blue. This variety will produce 60 to 70 per cent of double blooms, the flowers being much larger than the old single type.

Double Blue Packet $15 \mathrm{c}$

Single Blue Height two feet. Packet 10c.

Double Mixed Contains various colors of double flowers. Packet $15 \mathrm{c}$.

\section{COREOPSIS GRANDIFLORA}

A hardy perennial bearing masses of golden yellow flowers throughout the major portion of the year. Splendid for cutting. Height 30 inches. Packet $15 \mathrm{c}$.

\section{CINERARIAS-H \& S PRIZE MIXED}

Our strain of giant flowering Cinerarias is generally recognized as one of the finest in America. The plants are compact in their habit, the foliage is large and bold, and is surmounted by trusses of glorious size and substance. Blossoms four to four and a half inches in diameter are quite common. The range of colors contained in the strain is unexcelled, running from purest white to darkest crimson, through all the intervening shades of purple, blue, lavender, indigo, rose, etc., with many handsome bi-colored flowers. Pkt., 50c.

\section{H \& S NEW GIANT FLOWERING COLUMBINES}

A grand strain of giant flowering, long spurred Columbines in a color series of matchless beauty. Columbines are splendid as cut flowers or for the production of masses of color in the garden. We have made a series of selections to color and although not entirely fixed a very high percentage will come true.

Blue A splendid selection of all shades from light to dark blue. Flowers are long spurred and of large size. Pkt., $25 \mathrm{c}$.

Pink Contains the various tones from light pink to darkest rose. Very choice. Pkt., 25c.

Mixed Including all shades from pure white to pink, rose, red, yellow, crimson, blue. and various bi-color flowers of superb quality and form. Pkt., 25c.

\section{DIASCEA BARBARAE}

A low-growing biennial plant from South Africa, bearing innumerable quantities of small salmon-colored blossoms.

The plants attain a height of some twelve inches and are literally smothered with their dainty salmon-colored flowers. A fine subject for beds or borders. Pkt., 25c.

\section{DELPHINIUM ELATUM (H \& S PRIZE MIXED}

A superb strain of the tall growing perennial Larkspur or Delphinium, the seed having been carefully saved from the very finest large flowered selected types. The seed we offer contains a high percentage of the lighter shades with an absence of objectionable purples, etc. Shades of sky blue, turcuoise, sapphire and similar shades predominate. Per packet $25 \mathrm{c}$. 


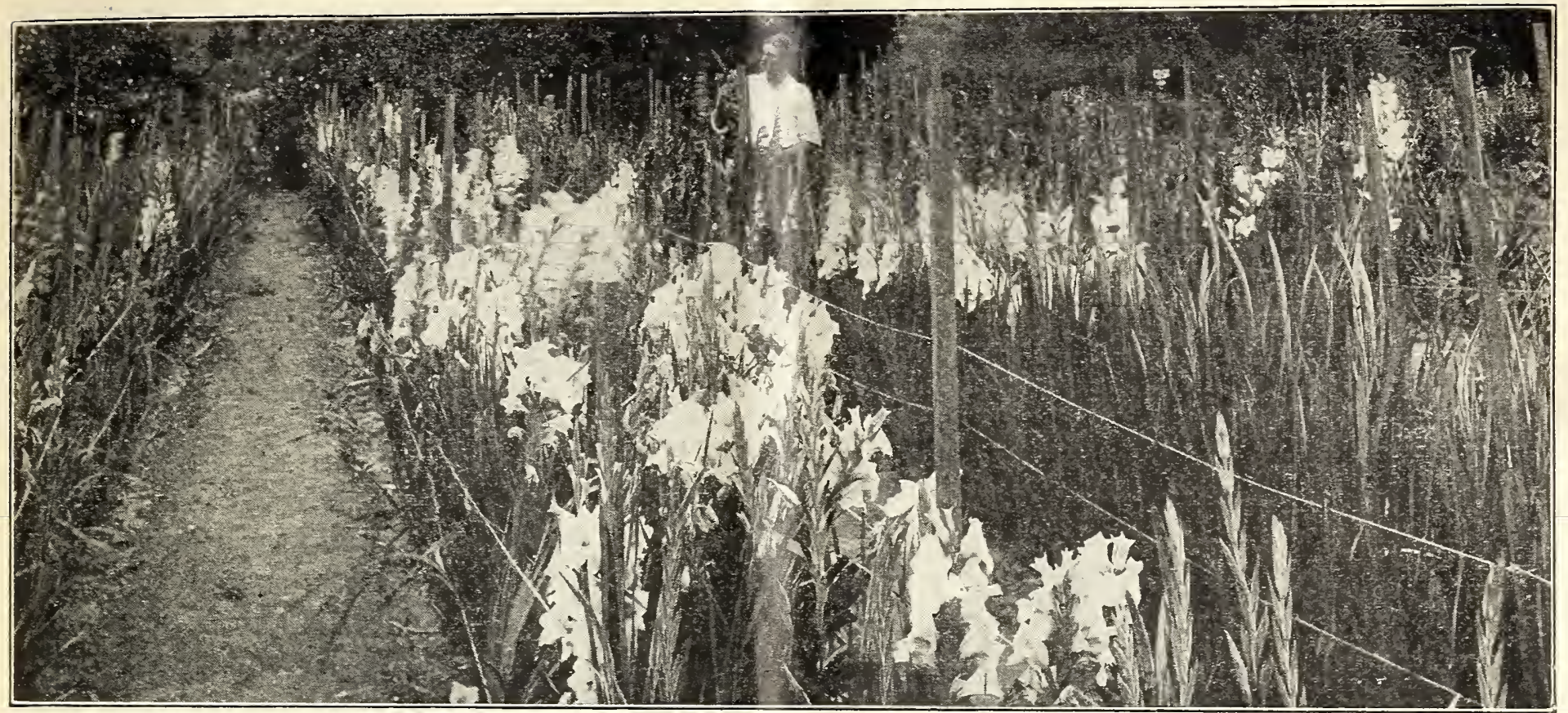

NEW SEEDLING GLADIOLUS AT OUR NURSERIES

\section{SHASTA DAISY}

Alaska A dainty pure white Shasta Daisy with large beau. tifully formed single flowers. This variety is unquestionably one of the best of all Shasta Daisies for cut flower purposes. Fine strong pot grown stock. Each $15 \mathrm{c}$; per dozen $\$ 1.50$.

\section{STOCKS}

No Spring garden can be considered complete without some of these showy annuals. Fine strong plants in 2-inch pots. Colors of crimson, white, pink, lilac and purple (midnight). 75 c per dozen; $\$ 5.00$ per 100 .

\section{THALICTRUM DIPTEROCARPUM}

A splendid but little known perennial. The plant in full growth somewhat resembles a maidenhair fern, the foliage being luxuriant and graceful. During the blooming period strong spikes shoot up from the center of the plant, bearing enormous quantities of minute bell-shaped flowers of a deep lilac or lavender color.

The small branches that support the flowers are so fine that at first the individual blossoms seem to be suspended in the air. In spite of the exquisite delicacy of their appearance, these flowers are ideal for cutting purposes, lasting over a long period of time in water. For basket work or for mixing with other flowers they are invaluable.

Fine strong plants, each $35 \mathrm{c}$; per dozen $\$ 3.50$.

\section{TRITOMAS}

For Summer and Fall blooming there are few plants more stately in appearance than well grown clumps of Tritomas. Their large, torch-like spikes of bloom reaching up to a height of six feet, and fine grassy foliage makes them conspicuous objects in the garden. They associate well with the various grasses, cannas, etc., in jungle effects, and do splendidly on the margins of artificial water courses and ponds. Once planted they increase in beauty each season, and require nothing more than plenty of water, any good garden soil and plenty of manure.

Chrysantha Bright lemon yellow. Four to five feet high. Each $35 \mathrm{c}$; per dozen $\$ 3.50$.

Henry A. Dreer An extremely large flowered, tall growing sort. Bright orange in color. Each $50 \mathrm{c}$; per dozen $\$ 5.00$.

\section{VIOLETS}

Princess of $\mathbb{W}$ ales The largest single violet in cultivation. Deliciously fragrant. Each 10c; per dozen $\$ 1.00$.

Marie Louise Large double blue flowers. Intensely fragrant and very free. Each $15 \mathrm{c}$; per dozen $\$ 1.50$.

Swanley White A perfectly double, pure white variety. Each $15 \mathrm{c}$; per dozen $\$ 1.50$.

Undine Light double blue. Very free flowering. Each 15c; per dozen $\$ 1.50$.

\section{New Perennial Hardy Flowering Pinks}

There have been but few novelties introduced in recent years more useful or beautiful than these superb new hardy Pinks from England. They are the result of crosses between the ordinary hothouse carnations and the small border pink. The flowers are intermediate in size between the carnation and the border variety. These pinks have a delightful clove fragrance. They are dwarf compact growers and blossom freely at all times of the year. A bunch of the cut flowers will scent a whole room, the fragrance being far stronger than that to be noted in any carnation. We can unhesitatingly recommend these beautiful new pinks to all of our customers. We offer them in three beautiful varieties.

Harold A beautiful deeply fringed, pure white ower with intense odor. Splendid for cutting.

Jean A dainty, deeply fringed, double variety. Center rich crimson, exterior of petals zoned white.
Phillis Pale pink with maroon colored center.

Young plants from two inch pots. Each 25c; per dozen $\$ 2.50$. 


\section{DIGITALIS (Foxgloves)}

Handsome, hardy plants of sturdy growth, succeeding under the most adverse conditions. Spikes four to five feet high with giant flowers in all shades of color. Unequalled for naturalizing in shrubberies at the edge of woods or other half shady places. Packet 15c.

Gloxinia Flowered White Immense spikes of pure white flowers.

Gloxinia Flowered Rose A splendid shade of deep rose.

Gloxinia Flowered Purple A rich shade of deep purple.

Gloxinia Flowered Mixed colors. Giant flowers spotted and shaped like Gloxinias.

Ivery's Spotted Like the former but with more conspicuous spots.

\section{NEW GIANT DAISIES}

(BELLIS PERENNIS MONSTROSA)

A highly improved strain of Daisies, remarkable for their immense foliage and extra large flowers. Blossoms attain a diameter on well grown plants of two inches and over and come true from seed. The value of Daisies for Spring bedding is well known and appreciateo

White A pure snowy white of very large size. Pkt., 25c. Rose A dainty shade of pure rose. Pkt., 25c.

\section{DELPHINIUM (PERENNIAL LARKSPUR)}

Shades of blue are exceedingly scarce in flowers, yet there is scarcely a shade which cannot be found in a good strain of choice perennial Larkspurs. Our seed of this particular strain is saved from a magnificent collection, one of absolutely unexcelled quality. A few of the shades to be noted in the mixture are sapphire, turquoise, gentian, sky blue, etc. As back row flowers in the herbaceous border they are well nigh indispensable. In English gardens they are invariably the most conspicuous and highly prized amongst herbaceous plants. You will find the strain all that we recommend it to be. Packet 25c.

Belladona A splendid variety of perennial Delphinium. The flowers are an exquisite shade of sky blue, and are borne on long wiry stems which makes them particularly valuable for cutting purposes. This variety blooms without intermission from early Spring until late Autumn and the clumps last from season to season, as it is a true perennial. Packet $25 \mathrm{c}$.

Blue Butterfly (Annual) A handsome annual variety which attains a height of some eighteen inches. The flowers are a rich, bright blue in color, grows easily from seed and blooms within a comparatively short space of time after sowing. Packet 15c

Azure Fairy A dainty dwarf annual Delphinium, a fine companion to Blue Butterfly. Flowers are a distinct shade of azure blue. The plants attain a height of about one foot and blossom from early Spring until late Autumn. Packet 25c.

\section{ESCHSCHOLTZIA (CALIFORNIA POPPY)}

Giant Orange Scarlet A remarkable selection and without question one of the handsomest of all types of California Poppies. Blooms exceedingly large. In color a luminous shade of rich orange scarlet. One of the finest novelties in annual plants introduced in a long time. Packet 25c.

Golden West Enormous flowers. Deep rich yellow with an intense orange colored center. Packet 10c.

Carmine King Flowers a distinct shade of bright carmine rose. Extra good. Packet 10c.

$W$ hite A good selection, creamy white flowers. Packet 10c.

\section{GERBERA (TRANSVAAL DAISIES)}

We were fortunate during the past season in being able to secure a fine lot of seed of these beautif ul Transvaal Daisies. The strain includes all colors from pure white to darkest crimson with all of the intervening shades of orange, yellow, pink, salmon, etc. These Gerberas are easily raised from seed and blossom the first season after sowing. As cut flowers they are unexcelled as they last over a week in water An extra choice mixture including all colors. Price per packet, 50c.
GYPSOPHILA

Although the flowers of Gypsophila in themselves are somewhat insignificant in character they tend to give a beautiful and feathery effect to flower arrangements of all kinds. The blossoms are produced in panicles. The individual flowers are quite small but are produced in great abundance. As a decorative accompaniment to sweet peas, carnations, etc, they are unexcelled.

Elegans Grandiflora (Annual.) Large flowered, pure white form. Can be flowered from seed within a few weeks after sowing. Packet 10c.

Paniculata A hardy perennial variety. Smaller flowers than Grandiflora but equally valuable for cut flower purposes. Packet $15 \mathrm{c}$.

\section{MYOSOTIS (FOR-GET-ME-NOT)}

Among the various flowers of early Spring there are few more appreciated than the various types of For-get-me-nots. All the colors are beautiful, from the pale blue of the Dissitiflora type to the deep blue Alpestris and the white and various rose colored shades. A liberal sowing made in Autumn or Winter will produce a large number of plants for blooming the following Spring. Height ten inches. Packets $15 \mathrm{c}$.

Dissitiflora A magnificent pale sky blue For-get-me-not. Very long stems. One of the best for cutting.

Alpestris, Blue A lovely shade of deepest blue.

Alpestris, White A pure white.

Alpestris, Rose A handsome shade of light rose.

Indigo Blue A charming new shade in for-get-me-nots, the color being a beautiful shade of indigo. It is richer and darker than any other variety. Wonderfully effective as a bedding plant and of splendid value for cutting purposes. Pkt., 25c.

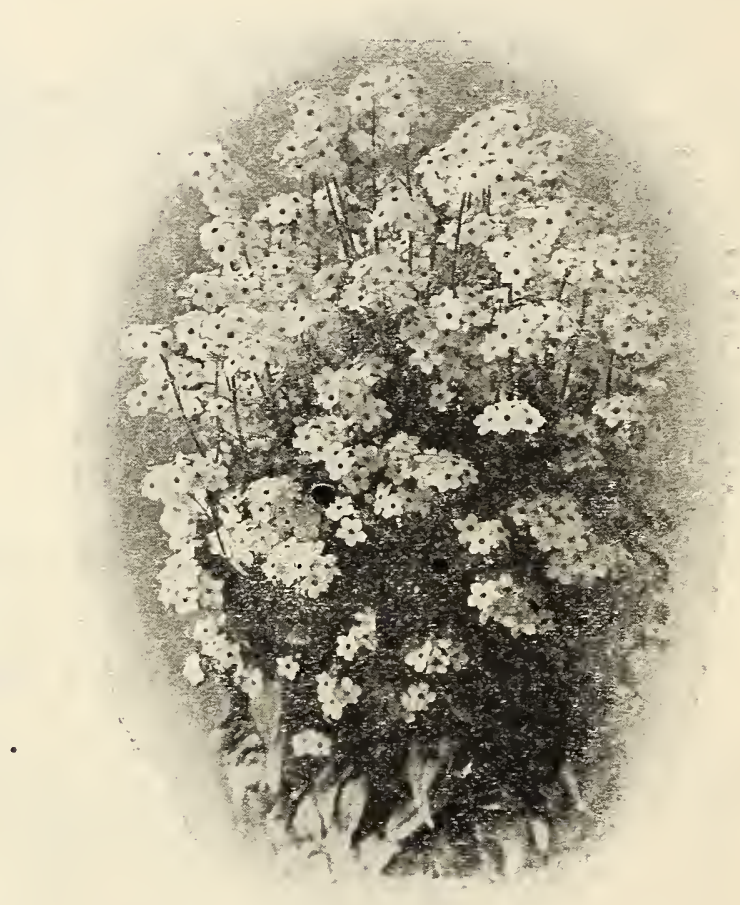

Myosotis Alpestris

\section{A BEAUTIFUL STRAIN OF PINKS (DIANTHUS PLU- MARIA) DOUBLE PERPETUAL}

A new strain of clove scented Pinks which originated in France. The blossoms are beautifully fringed, large in size and produced in endless profusion throughout the entire season. They are as deliciously scented as the old fashioned clove pink, with the additional advantage that the flowering extends over a much greater period of time. Easily raised from seed, and if sown early will blossom the same season. Quite hardy and should be planted in every garden. All colors mixed. Pkt., 50c. 


\section{CHOICE PANSIES}

Giant Coal Black Mammoth blossoms, absolutely black. Small yellow eye. Price per pkt. 25c.

Giant White With yellow eye. Price per pkt. 25c.

Giant Victoria One of the best reds. Price per pkt. 25c.

Giant Lord Beaconsfield Purple violet. Price per pkt. 25c.

Giant Orchid flowered Andromeda Rose and Lavender.

Price per pkt. $25 \mathrm{c}$.

Giant Prince Henry Darkest rose, very large. Price per pkt. $25 \mathrm{c}$.

Giant Golden Queen Pure yellow, very fine. Price per pkt. 25c.

Giant Francis Joseph White with violet spots. Price 25c per pkt.

Giant Adonis Light blue. Price per pkt. 25c.

Giant Orchid flowered mixed A superb strain of mixed colors in unique shades. Price per pkt. 25c.

Giant Yellow With black eye. Price per pkt. 25c.

H. \& S. Prize Mixed A mixture of all of the foregoing varieties and many other beautiful and diverse shades. A strain of Pansies of ne plue ultra quality. There is nothing finer in existence. Per packet 50c.

\section{POPPY}

Poppy seed should be sown where the plants are intended to flower. It is difficult to transplant them with any degree of success. In the strains which we offer you below you will find not only a wide selection of colors, but the best obtainable in their respective classes.

\section{DOUBLE SHIRLEY POPPIES}

One of the most valuable introductions by way of a new strain of annuals to be noted in a long time. The beauty of the well known single type of Shirley Poppy is even accenuated in this wonderful new strain of doubles. It contains a remarkable assortment of colors with beautifully frilled and undulated petals. It is a strain we recommend all of our customers to try for we are certain they will be more than pleased with the -esult. Packet 25c.

Re-Selected Shirley A superb strain containing all shades it coiors from purest white through the various shades of pink, salmon, rose, maize, etc. Scarcely any two of the blooms are vike. Packet $15 \mathrm{c}$.

Carnation Flowered, Mixed Splendid double fringed blossoms. Packet $10 \mathrm{c}$.

Paeony Flowered, Mixed Large double paeony-like flowers. well adapted for planting in beds or borders, etc. Packet 10c.

\section{WINTER AND SPRING FLOWERING STOCKS}

These are one of the most important of all annuals, either for bedding or cut flower purposes during the cooler months of the year. They will stand several degrees of frost without injury and produce bountiful crops of bloom at a time when flowers are often scarce in the garden. Our strains of these have been grown at our Rivera nurseries and produce an exceedingly high percentage of splendid double blooms.

\section{TWO HANDSOME BEDDING STOCKS}

Dwarf Rose An exquisite shade of fresh glistening ruse. Per pkt. 15c.

Dwarf White A splendid companion to the foregoing. Plants compact and bushy. Attain a height of some 15 inches. Very fine for pot work. Per pkt. 15c.

\section{STOCKS IN TALLER VARIETIES}

Eight splendid tall growing stocks. Following are all of the Nice type and are the best of all stocks for cutting purposes, as the stems are quite long. The plants attain a height of some 30 inches. We offer them in the following colors at $15 \mathrm{c}$ per pkt.

Giant Deep Rose A pure even shade.

Giant Beauty of Nice Soft pink.

Giant Old Rose An art shade of splendid value.

Giant Canary Yellow A highly desirable yellow stock.

Giant Rose on Cream Ground A splendid combination of colors.

Giant Deep Lilac Extra fine.

Giant Purple Pure and even in tone.

\section{SWEET WILLIAM}

One of the most highly esteemed of all hardy garden plants. They are not only of easy culture, thriving in any garden soil, but produce a wonderful show of color each succeeding Spring. Although the plants last over two seasons, it is generally advisable to make a fresh sowing each Spring, for blossoming the following year. Height twelve inches. Packet $15 \mathrm{c}$.

Pink Beauty Single. Beautiful pure pink.

Harlequin Unique owing to the fact that it bears a number of different colored blooms on the same plant.

New Annual A new strain bearing large heads of bloom and flowering the same season the seed is sown. It may be depended upon to blossom within some ninety to a hundred and twenty days after sowing.

\section{VIOLA PAPILIO}

A handsome light blue bedding Viola, a variety which comes nearly true from seed and bears during the autumn, winter and spring months, veritable masses of medium-size flowers. Although this Viola is not as large as many pansies, it more than makes up for its deficiency in this respect by its remarkable producton of blooms. From seed sown in July or August, the plants will produce a carpet of flowers from November to May. Per packet 25c.

\section{WALLFLOWERS}

New early flowering varieties which can be ireated as annuals. If sown early in seed beds, will bloom freely during the coming Summer and Autumn.

Early Paris Market Light brown. Packet 15c.

Golden Gem Bright golden yellow. Packet 15c.

Blood Red Packet 15c.

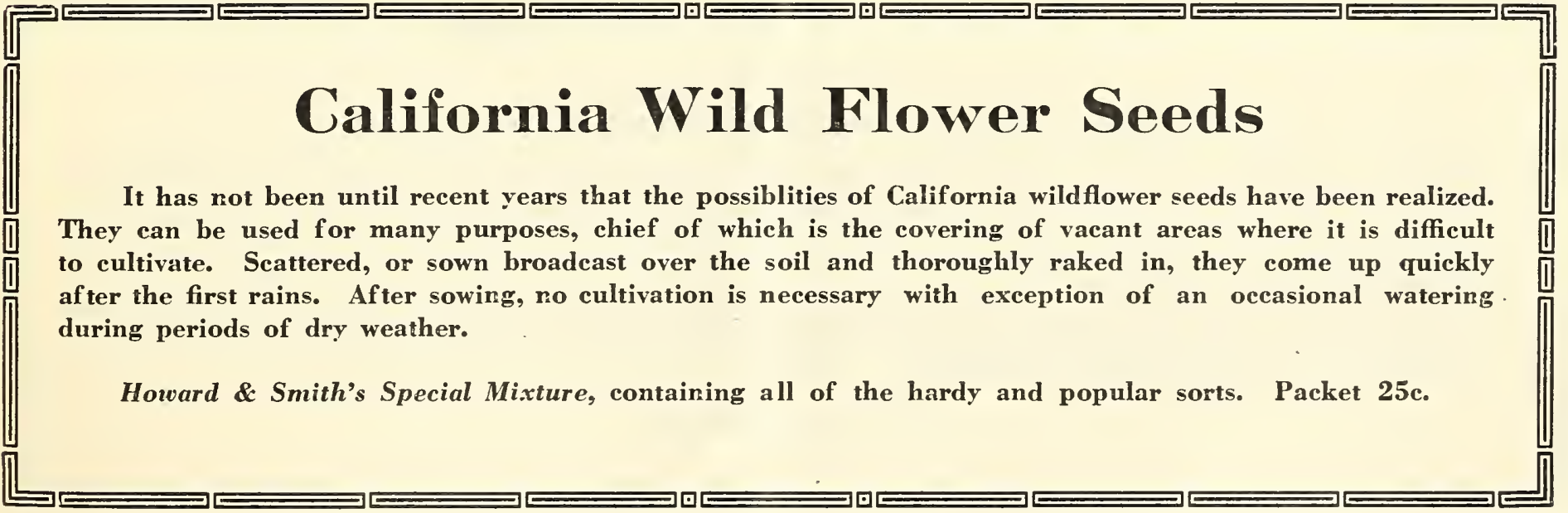




\section{SWEET PEAS}

\section{Spring and Summer \\ Late Flowering}

Do not fail to make a sowing of these superb Spring and Summer blooming Sweet Peas. They will begin to blossom when three or four feet high and furnish a continuous display of flower 3 from April to July. The seed we offer has been saved exclusively from the very best selected types of Spencer blooms. It is hand-picked, plump, bound to germinate and bound to give you satisfaction.

\section{TEN SUPERB NEW VARIETIES}

Latest addition to Sweet Peas by way of color, size and length of stem.

Agricola White overlaid soft lilac.

Afterglow Reddish mauve with violet wings.

Blue Jacket Rich deep blue. One of the very best.

Constance Hinton The best giant pure white.

Duplex Pink A superb selection. Double. Countess of Spencer type. Extra large.

Lady Evelyn Eyre Pale pink, slightly flushed salmon.

Margaret Atlee Warm salmon pink overlaying cream ground. Extra large.

New Margaret Madison Best pale lavender.

Royal Purple Immense flowered, deep rich purple.

Wedgewood Lovely shade of light blue.

Price of any of the foregoing sweet peas, liberal packages. Packet 25c.

\section{SPECIAL OFFER}

One package of each of the above superb varie. t'es, ten in all, for $\$ 2.00$.

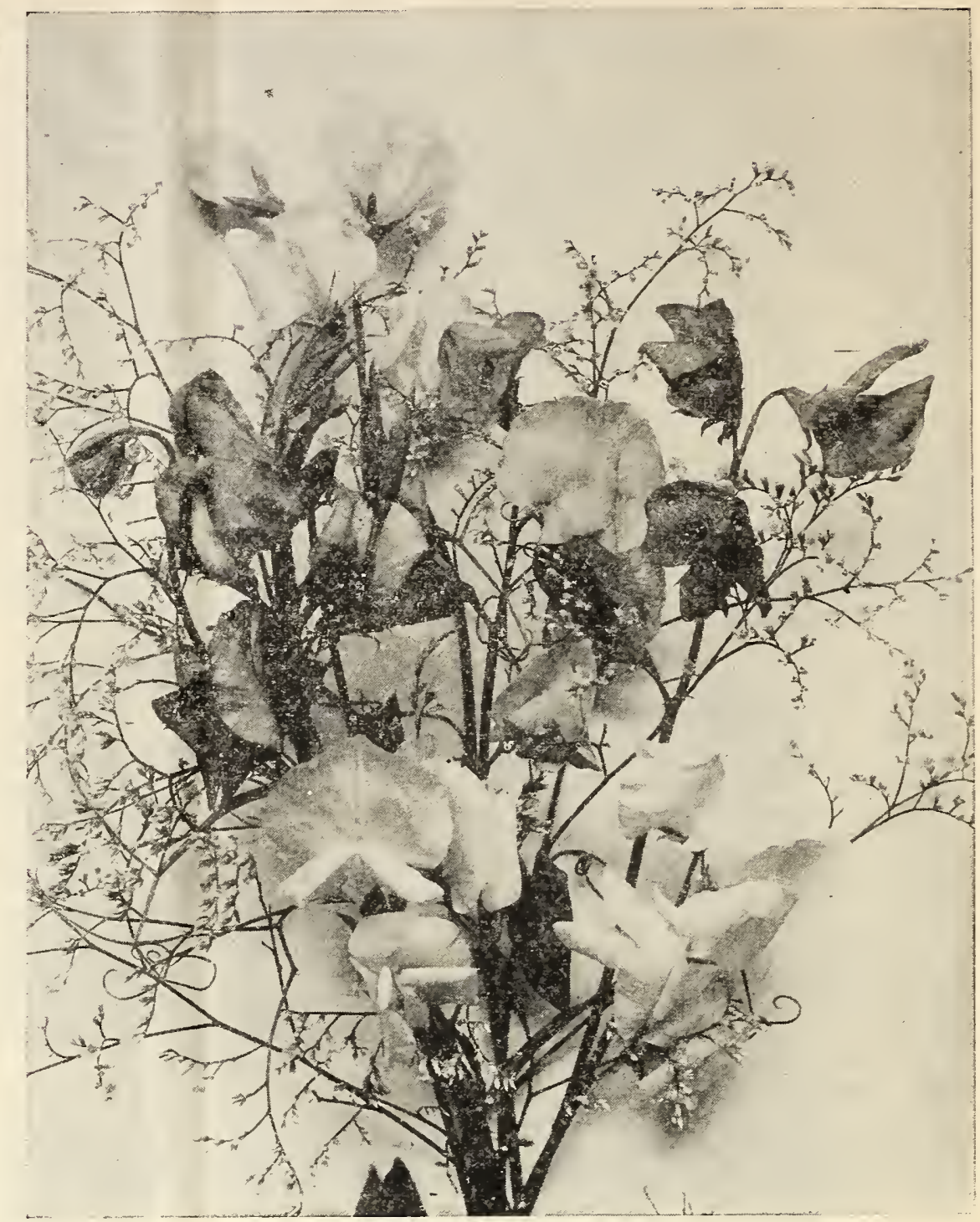

Sweet Peas Arranged with Sprays of Statice Latifolia

\section{TEN SUPERB STANDARD VARIETIES OF SWEET PEAS}

America Ivory white, striped crimson.

Countess of Spencer Beautiful clear pink.

Elfrida Pearson Lovely shade of soft pink.

Florence Nightingale Delicate soft lavender.

Helen Lewis Deep orange rose.

King Edward Superb crimson scarlet.

Mrs. Routzahn Straw, tinted with blush pink.

Mrs. Hugh Dickson Creamy pink.
Nubian Deep chocolate.

Vermillion Brilliant Deep, rich scarlet.

Price of any of the foregoing, packet $15 \mathrm{c}$.

All colors mixed, packet $15 \mathrm{c}$.

\section{SPECIAL OFFER}

One of each of the above ten varieties of standard sweet peas for $\$ 1.25$.

\section{GLITTERS}

\section{A SENSATION NOVELTY IN WINTER FLOWERING SWEET PEAS}

This variety is easily one of the most sensational novelties ever offered in the section of winter flowering Sweet Peas. We know of nothing which approaches it in richness of color or size of blooms. It is a variety which is unique in itself, the color is a bright fiery orange salmon. The flowers are of enormous size, are beautifully waved, usually borne four to the stem. As a cut flower variety, especially for use under artificial light, it is without peer.

While we have sent out many new winter flowering Sweet Peas, and our collection of this particular class is representative of the best types, we can say that this variety is the best of the entire lot. We have only a limited amount of seed to offer this season.

Price per packet, 25c. 


\section{Winter Flowering Sweet Peas}

Sow them now. Soon the fertile seed will sprout, followed by a luxuriant growth of green. A few short weeks of autumn's golden sunshine and behold!- the bank of green is hidden by a wealth of dainty flowers.

Enchantress An exquisite shade of bright rosy pink, shading to deeper color toward the edges of the petals. A flower of immense size and beautiful wavy outiine. Price, per pkt., $25 \mathrm{c}$

Glorious Deep royal purple with stems of great length and flowers of gigantic size. Price, per pkt., 25c.

Gorgeous Lovely soft salmon rose, in cool weather turning to cerise. Very long stems. Price, per pkt., 25c.

Lavender King A delicate shade of deep lavender, uniform in color throughout the entire flower. Price, per pkt., 25c.

Maroon Prince A distinct shade of glowing reddish inaroon. Very large flowers. Price, per pkt., 25c.

Pink and White A greatly improved variety with beautiful wavy wings. Blooms of mammoth size. Price, per pkt., $25 \mathrm{c}$.
Rosebud Bright shiny rose with a suffusion of bronze at the base of the standard. A superb variety. Price, per pkt., 25c

Snowstorm Dainty pure white with large fluffy blossoms Price, per pkt., 25c.

Splendor A delightful shade of rosy crimson. In cool weather this strain produces pure dark rose colored flowers. Price, per pkt., 25c.

Yarrawa Splendid bright rosy pink, tinted with cream at the base of the petals. Price, per pkt., 25c.

H. \& S. Prize Mixed A well balanced mixture containing all of the above listed varieties. Price, per pkt., 25c.

Complete collection $\$ 2.50$.

\section{Hydliangeas}

It is with pleasure that we direct the attention of our customers to the splendid collection of Hydrangeas noted below. With the exception of the variety Otaska they are all new hybrids of French origin and have created a sensation wherever they have been shown. Until the advent of thes e new hybrids he colors in Hydrangeas were confined to either pink or white, whereas in this new set an immense $r$ ange of charming colors have been added. The trusses and blooms of nearly all of the sorts are of phenomenal size. The fact that Hydrangeas thrive in shady places makes them especially valuable in north borders, etc., where only too often it is difficult to obtain definite or permanent color effects.

\section{HYDRANGEA TROPHEE}

A superb new variety, distinct in every particular from any Hydrangea hitherto introduced. The color is a bril. liant shade of carmine rose-the nearest approach to a red to be noted in this class of plants. Easily one of the finest novelties in any class of plants of recent introduction. Price each 50c.

Avalanche Superb variety with immense panicles of pure white flowers.

Bouquet Rose Rich pink, turning to light pink.

Botaniste Poltereau A pretty shade of mauve rose.

Fraicheur White with dainty suffusions of rose.

Innocence A splendid compact growing variety. Pure white. Trusses of medium size.

La Lorraine Pale rose turning to bright pink.

Mlle. De Tremault A pure white of distinct form. Extra good.

Mlle, Agne Barillet One of the earliest blooming whites.

Very refined form.

Mlle. Renee Gaillard Pure white with fringed florets.

Mad. Raymond White passing to roce.
Mad. E. Mouillere A variety with trusses and individual florets of phenomenal size. White, occasionally tinted with pink.

Mad. M. Hamar A superb shade of delicate blush rose.

Mad. A. Riverain Brilliant blush rose.

Mousseline Very large trusses. Light pink with a cream colored center.

Mons. G. Renault Bright rose with carmine reflex.

Ornament Extra large flowers. Mauve pink.

Radiant Rich rosy carmine.

Souv. de Mad. E. Chautard A free blooming and very early pink variety.

Senateur Henri David Superb flowers of delicate pale rose color.

Vieux Chateau White with suffusion of rosy carmine.

Viscountess de Vibraye Rosy pink.

Otaksa Montrosa One of the older varieties. Always good. Color blush pink. Trusses extra large.

PRICE of any of the foregoing varieties, strong young plants from four inch pots: Each $50 \mathrm{c}$; per doz. $\$ 5.00$.

\section{ANNOUNCEMENT}

WE TAKE PLEASURE IN CALLING YOUR ATTENTION TO THE SEVEN-ACRE SUNKEN GARDEN AT EXPOSITION PARK, A PERMANENT FREE EXHIBIT MAINTAINED JOINTLY BY THE CITY AND COUNTY OF LOS ANGELES UNDER THE AUSPICES OF THE CALIFORNIA NURSERYMEN'S ASSOCIATION. THE OBJECT OF THIS GARDEN IS TO DEMONSTRATE THE GREAT VARIETY OF FLOWERING AND ORNAMENTAL PLANTS WHICH CAN BE SUCCESSFULLY GROWN IN THE OPEN GROUND AT ALL SEASONS OF THE YEAR. A FREQUENT VISIT TO THESE GROUNDS WILL BE WELL WORTH THE TIME OF ANYONE INTERESTED IN THEIR GARDEN. 
